\title{
PENGEMBANGAN LEMBAR KERJA ANAK (LKA) MODEL STEM PADA KONSEP TERAPUNG MELAYANG TENGGELAM UNTUK MEMFASILITASI KETERAMPILAN SAINTIFIK ANAK USIA DINI
}

\author{
Resa Pujiaswati ${ }^{1,}$ Edi Hendri Mulyana ${ }^{2,}$ Sima Mulyadi $^{3}$ \\ ${ }^{1}$ Program Studi PGPAUD UPI Kampus Tasikmalaya \\ ${ }^{2}$ Program Studi PGPAUD UPI Kampus Tasikmalaya \\ ${ }^{3}$ Program Studi PGPAUD UPI Kampus Tasikmalaya
}

Email: resapujiaswati20@gmail.com

(Received: Mei 2020; Accepted: Mei 2020; Published: Juni 2020)

\begin{abstract}
The form of a child's worksheet generally contains evaluation questions that serve as a child's cognitive assessment. But actually worksheets are used to facilitate children to do learning activities in understanding a concept/ knowledge. The 2013 curriculum is present as a guide in determining learning and requires teachers to educate students through various activities in order to have scientific skills. Whit the 2013 curriculum, STEM (Science, Technology, Engineering, and Mathematic) learning is expected to facilitate integrative learning activities that apply to early childhood education. This study aims to develop worksheets for STEM child models to facilitate children's scientific skills. In this stufy, the researcher will explain the basic needs and design the development of STEM model worksheets for floating concept of drowning to facilitate children's scientific skills after early age. The method used in this research is the development of Educational Design Research. Then based on the needs and findings in the field, the researcher will develop the STEM Model Worksheet for the Drowning Floating Concept to Facilitate Scientific Skills of Early Childhood, so that it can be implemented in early childhood.
\end{abstract}

\begin{abstract}
ABSTRAK
Bentuk lembar kerja anak pada umumnya berisi mengenai soal evaluasi yang dijadikan sebagai penilaian kognitif anak. Namun sebenarnya lembar kerja digunakan untuk memfasilitasi anak melakukan kegiatan belajar dalam memahami suatu konsep/pengetahuan. Kurikulum 2013 hadir sebagai pedoman dalam menentukan pembelajaran dan mengharuskan guru untuk mendidik siswa melalui berbagai aktivitas agar memiliki keterampilan saintifik. Dengan adanya kurikulum 2013 tersebut pembelajaran STEM (Science, Technology, Engineering, and Mathematic) diharapkan dapat memfasilitasi kegiatan pembelajaran integratif yang berlaku pada pendidikan anak usia dini. Penelitian ini bertujuan untuk mendeskripsikan dasar kebutuahn penggunaan lembar kerja anak dan mengembangkan lembar kerja anak model STEM untuk memfasilitasi keterampilan saintifik anak. Pada penelitian ini, peneliti akan menjelaskan mengenai dasar kebutuhan dan membuat rancangan pengembangan lembar kerja anak model STEM pada konsep terapung melayang tenggelam untuk memfasilitasi keterampilan saintifik anak usia dini. Metode yang digunakan dalam penelitian ini adalah pengembangan Educational Design Research. Penerapan pembelajaran STEM dengan menggunakan LKS akan menjembatani pembelajaran tematik integratif yang menerapkan pada 4 bidang keilmuan, kemudian akan menghasilkan suatu produk memfasilitasi keterampilan saintifik anak. Pembelajaran sains pada usia dini masih dirasa cukup sulit, namun dengan media dan bahn ajar yang memadai, maka hal tersebut dapat diatasi. Berdasarkan studi literatur ditemukan bahwa banyak lembar kerja anak yang tidak sesuai dengan tahap perkembangan anak. Maka berdasarkan kebutuhan dan penemuan dilapangan tersebut, peneliti akan melakukan Pengembangan Lembar Kerja Anak Model STEM pada Konsep Terapung Melayang Tenggelam untuk Memfasilitasi Keterampilan Saintifik Anak Usia Dini, sehingga dapat diimplementasikan pada anak usia dini.
\end{abstract}

Keyword: Work Sheet, STEM, Scientific Skills 


\section{PENDAHULUAN}

Pendidikan merupakan hal yang sangat penting bagi kehidupan manusia. Maka dari itu perlu diadakan pendidikan awal anak usia dini untuk pertumbuhan dan perkembangannya sebagai seorang manusia. Sujiono (2012, hlm. 6) berpendapat bahwa PAUD menitikberatkan pada peletakan dasar kearah pertumbuhan dan perkembangan fisik motorik, bahasa, kognitif, sosial emosional, agama dan juga seni, sesuai dengan keunikan tahap-tahap perkembangan masing-masing anak yang telah termuat dalam kurikulum 2013. Pembelajaran yang dilaksanakan di PAUD mendorong anak agar belajar secara aktif untuk membangun pengetahuannya sendiri. Sesuai dengan kurikulum tersebut, pembelajaran STEM (Science, Technology, Engineering, \& Mathematics) dapat digunakan untuk mengoptimalkan proses pembelajaran anak karena berorientasi pada aktivitas siswa yang difasilitasi oleh guru. Pada pembelajaran di PAUD tersebut tidak terlepas dari penggunaan media dan LKA untuk memfasilitasi anak. LKA tersebut seharusnya digunakan untuk memudahkan siswa dalam pembelajaran agar lebih aktif dibanding dengan guru.

Namun fakta dilapangan menunjukkan bahwa guru masih menggunakan metode ceramah yang berarti menggunakan pembelajaran konvensional sehingga pembelajaran berpusat pada guru. Selain itu guru masih belum menerapkan pembelajaran berbasis STEM untuk anak usia dini. Penggunaan LKA dalam proses pembelajaran pun belum cukup optimal. Banyak LKA yang masih tidak sesuai dengan tujuan pembelajaran. LKA yang digunakan belum mendukung untuk pembelajaran siswa yang aktif dan mandiri. Penjelasan tersebut dimaknai bahwa siswa belum aktif dalam proses pembelajaran karena masih terpusat pada guru. Sehingga, proses pembelajaran tersebut belum sesuai dengan karakteristik pembelajaran di PAUD.

Berdasarkan hasil observasi kebeberapa TK, masih jarang sekolah yang menggunakan pembelajaran STEM, karena sebagian besar guru kurang memahami makna dari pembelajaran STEM tersebut. Namun untuk pembelajaran sains sudah mulai dilakukan dibeberapa sekolah tersebut meskipun belum menggunakan LKA secara maksimal. Guru berpendapat bahwa sains terlalu sulit untuk dibuatkan LKA. Selain itu juga banyak ditemukan LKA yang tidak sesuai dengan aspek pengembangan terutama untuk memfasilitasi keterampilan proses saintifik. Grossman (1996) menyatakan "Worksheets typically have a right answer." Kegiatan lembar kerja yang tidak sesuai dengan perkembangan akan menimbulkan masalah. Sebaliknya, LKA yang sesuai dengan tahap perkembangan dan kemampuan anak akan berdampak baik. Prastowo (2012, hlm. 203) menyatakan bahwa LKS adalah lembaran berisi tugas yang harus dikerjakan oleh peserta didik, berupa petunjuk atau langkahlangkah kerja untuk menyelesaikan suatu tugas sesuai kompetensi dasar yang akan dicapai. Dengan demikian LKA digunakan untuk memfasilitasi anak dalam pembelajaran agar dapat memahami materi dengan baik, bukan untuk mematahkan kreativitas anak. Selain mudah dipelajari oleh anak, LKA diharapkan bisa mengembangkan berbagai aspek keterampilan anak termasuk keterampilan saintifik.

Menurut Peraturan Menteri Pendidikan dan Kebudayaan Republik Indonesia Nomor 146 Tahun 2014, keterampilan saintifik yaitu: mengamati; menanya; mengumpulkan informasi; menalar dan mengomunikasikan hasil. Pada hal ini STEM merupakan pembelajaran yang efektif dalam pembelajaran tematik integratif dan saintifik, karena dalam pembelajaran tersebut memuat 
beberapa bidang keilmuan yaitu "Science, Technology, Engineering, \& Mathematics". Dalam pembelajaran STEM anak mempelajari konsep sains melalui pengamatan termasuk konsep terapung melayang tenggelam. Menurut Firman (2015, hlm. 3) Pendidikan STEM memberikan peluang guru untuk memperlihatkan kepada peserta didik betapa konsep, prinsip dan teknik dari STEM yang digunakan dalam kehidupan sehari-hari mereka. Pembelajaran STEM ini membantu anak untuk mempersiapkan diri dikehidupan selanjutnya pada abad 21 .

Berdasarkan latar belakang tersebut maka rumusan masalah yang akan dibahas adalah dasar kebutuhan dan rancangan pengembangan lembar kerja anak model STEM pada konsep terapung melayang tenggelam untuk memfasilitasi keterampilan saintifik anak usia dini.

Tujuan dari penelitian ini ialah untuk mendeskripsikan dasar kebutuhan pengunaan lembar kerja dan mengembangakn lembar kerja anak pada konsep terapung melayang tenggelam untuk memfasilitasi keterampilan saintifik anak usia dini.

Maka dari itu peneliti akan melakukan penelitian dengan judul "Pengembangan Lembar Kerja Anak (LKA) Model STEM (Science, Technology, Engineering, and Mathematics) pada Konsep Terapung Melayang Tenggelam untuk Memfasilitasi Keterampilan Saintifik Anak Usia Dini”

\section{TINJAUAN PUSTAKA}

a. Pembelajaran Sains (Konsep Terapung Melayang Tenggelam) untuk Anak Usia Dini

Pendidikan anak usia dini merupakan pendidikan yang ditujukan dan disediakan untuk anak usia dini. Menurut Suyadi \& Ulfah (2013, Hlm. 2) "Usia dini (0-6 tahun) merupakan masa perkembangan dan pertumbuhan yang sangat menentukan bagi anak dimasa depannya atau disebut juga masa keemasan (the golden age) sekaligus periode yang sangat kritis yang menentukan tahap pertumbuhan dan perkembangan anak selanjutnya". Maka dari itu, perlu adanya pendidikan yang baik dan berkualitas sebagai titik awal dalam pembentukan karakter dan pertumbuhannya dimasa depan. Termasuk dalam memberikan pemahaman mengenai sains.

Pengembangan konsep sains didasarkan pada sifat yang dimiliki anak secara alami. Anak mempelajari sains diperuntukkan agar anak mampu mengenal konsep yang terjadi di sekelilingnya, dan bisa mengeksplor proses sebab-akibat dari fenomena yang ada di lingkungan anak. Klarissa, dkk (2018, hlm. 283) berpendapat bahwa pengenalan sains pada anak usia dini sangat penting karena dapat merangsang anak untuk berpikir kritis terhadap lingkungannya, juga menstimulus untuk meningkatkan rasa ingin tahu, minat dan pemecahan masalah sehingga memunculkan pemikiran dari perbuatan seperti mengobservasi, berpikir dan mengkaitkan antar konsep dan peristiwa. Pendekatan saintifik tidak diartikan sebagai belajar sains, tetapi dalam kegiatan belajar menggunakan proses saintis (Klarissa dkk, 2018, hlm. 284). Sains membekali anak agar belajar berbasis riset, seperti seorang ilmuan dengan cara menyikapi alam dan cara memecahkan masalah sederhana, melatih untuk menjelaskan suatu peristiwa, melatih anak bekerja sesuai dengan masalah yang dihadapi.

Salah satu konsep sains yang dapat kita ajarkan pada anak usia dini yaitu konsep terapung, melayang dan tenggelam. Konsep tersebut dipengaruhi oleh Hukum archimedes yang menjelaskan bahwa suatu benda yang dicelupkan sebagian atau seluruhnya ke dalam zat cair akan mengalami gaya apung yang besarnya sama dengan berat zat cair yang 
dipindahkan oleh benda tersebut (Pertiwi ,2017). Benda terapung terjadi jika massa jenis benda lebih kecil dari massa jenis zat cair. Benda melayang terjadi jika massa jenis benda sama besar dengan massa jenis zat cair. Benda tenggelam terjadi jika massa jenis benda lebih besar dari massa jenis zat cair (Utami, 2014).

Konsep tersebut sudah bisa diajarkan pada anak usia dini, karena fenomena tersebut terjadi disekeliling anak. Penyampaian konsep tersebut bisa dilakukan dengan permainan sederhana yang diminati oleh anak. Anak diajak secara langsung melakukan percobaan tersebut dengan pendekatan saintifik. Sehingga anak mampu mengetahui konsep tersebut dengan sendirinya.

\section{b. Keterampilan Saintifik Anak Usia Dini}

Sehubungan dengan pendidikan di Indonesia yang sudah menerapkan kurikulum 2013 dimana lebih menekankan untuk menggunakan pendekatan saintifik, maka anak dianjurkan untuk menguasai keterampilan saintifik. Pendekatan saintifik adalah proses pembelajaran yang dirancang agar anak secara aktif membangun konsep, hukum dan prinsip melalui tahapan mengamati (mengindentifikasi atau menemukan masalah), merumuskan masalah, mengajukan atau merumuskan hipotesis, mengumpulkan informasi dengan berbagai teknik, menganalisis informasi, dan menarik kesimpulan dan mengomunikasikan konsep, hukum atau prinsip yang ditemukan (Hosnan, 2014, hlm. 34). Melalui pendekatan ini anak diharapkan mempunyai keterampilan saintifik untuk bekal dimasa depannya.

Keterampilan saintifik menurut Peraturan Menteri Pendidikan dan Kebudayaan Republik Indonesia Nomor 146 Tahun 2014, yaitu: mengamati; menanya; mengumpulkan informasi; menalar dan mengomunikasikan hasil. Menurut Rusman (2017, hlm. 422) "Pendekatan saintifik adalah cara yang digunakan untuk memberikan kesempatan kepada anak melalui kegiatan mengamati, menanya, menalar, mencoba untuk melakukan ekspolasi dan elaborasi materi yang dipelajari”. Dari kegiatan saintifik anak diajarkan untuk mengamati dan menyimpulkan hasil dari temuannya dalam pembelajaran tersebut. Menurut Gultom, E. L. (2017) ada beberapa alasan perlunya pendekatan saintifik untuk AUD, yaitu :

1) Mendorong anak agar memiliki kemampuan berpikir kritis, analitis, dan memiliki kemampuan memecahkan masalah.

2) Memberikan pengalaman belajar yang lebih bermakna kepada anak dengan mendorong anak melakukan kegiatan mengamati,menanya, mengumpulkan informasi, menalar/mengasosiasi,dan mengomunikasikan.

3) Mendorong anak mencari tahu dari berbagai sumber melalui observasi dan bukan hanya diberitahu.

Dari penjelasan tersebut dapat disimpulkan bahwa pendekatan saintifik sangat efektif digunakan di PAUD untuk mengembangkan potensi dan keterampilan anak.

\section{c. Pembelajaran STEM}

Istilah STEM dikenalkan oleh NSF (National Science Foundation) Amerika Serikat pada tahun 1990-an sebagai singkatan dari "Science, Technology, Engineering, \& Mathematics". Menurut Sukmana (2017, hlm. 192) "STEM merupakan sebuah pendekatan pembelajaran yang populer di tingkat dunia yang efektif dalam menerapkan pembelajaran tematik integratif karena menggabungkan empat bidang pokok dalam pendidikan yaitu ilmu pengetahuan, teknologi, teknik dan matematika". Menurut Chesloff (dalam Rini, dkk, 2019, hlm. 9) "Pendidikan STEM harus dimulai pada anak usia dini karena konsep jantung STEM adalah rasa ingin tahu, 
kreativitas, kolaborasi, pemikiran kritis sangat diminati".

Terdapat tiga pendekatan untuk pengajaran pendidikan STEM yang saat ini sedang dipraktikan menurut Roberts dan Cantu (2012, hlm. 112 - 114) yaitu, silo, tertanam dan terpadu. Untuk PAUD pendekatan terpadu dirasa sangat efektif digunakan dalam pembelajaran, karena mengintegrasi semua disimpilin ilmu tanpa ada batasan konten, sehingga anak lebih mudah melakukan pembelajaran.

\section{d. Lembar Kerja Anak}

Lembar kerja anak atau yang lebih dikenal dengan lembar kerja siswa adalah lembaran pekerjaan yang harus dikerjakan siswa untuk membantu proses pembelajaran. Menurut Prastowo lembar kerja siswa (Student Work Sheet) adalah "Lembaran-lembaran yang harus dikerjakan oleh peserta didik". Lembar tersebut biasanya berupa petunjuk atau langkah-langkah untuk menyelesaikan suatu tugas. Dan tugas tersebut harus sesuai dengan kompetensi yang akan dicapai (Prastowo, 2012, hlm. 204). Lembar kerja anak dibuat dan dikembangkan oleh guru sebagai fasilitator dalam kegiatan pembelajaran yang dapat membantu kemandirian siswa. Umiyati dkk. (2018, hlm. 123) menyatakan bahwa "Lembar kerja peserts didik adalah salah satu alternatif pilihan yang lebih sesuai sebagai media pembelajaran dalam proses pembelajaran anak, melalui soal-soal bergambar yang menarik diharapkan bisa lebih mudah dalam memahami materi melalui kegiatan saintifik. Karena pada anak usia dini anak-anak lebih menyukai gambar daripada tulisan". Pemahaman pembelajaran dengan menggunakan Lembar Kerja Anak (LKA) akan lebih mudah diserap dan tidak akan mudah hilang, sebab anak diarahkan bukan hanya melalui tulisan, namun juga urutan soal-soal bergambar.
Prastowo (2012, hlm. 205) menjelaskan mengenai fungsi lembar kerja untuk siswa yakni sebagai berikut:

1) Sebagai bahan ajar yang bisa meminimalkan peran pendidik, namun lebih mengaktifkan peserta didik

2) Sebagai bahan ajar yang mempermudah peserta didik untuk memahami materi yang diberikan

3) Sebagai bahan ajar yang ringkas dan kaya tugas untuk berlatih; serta

4) Mempermudah pelaksanaan pengajaran kepada peserta didik.

LKA yang dibuat juga harus memperhatikan ketentuan yang ada agar bermanfaat sesuai fungsinya. Tiga persyaratan kualitas penyusunan lembar kerja untuk siswa menurut Hendro Darmodjo \& Jenny R.E (dalam Pertiwi, 2017) adalah:

1) Didaktik, yakni mengatur tentang penggunaan LKA yang bersifat universal dapat digunakan dengan baik untuk siswa yang lamban ataupun yang pandai, dan lebih menekankan pada proses untuk menemukan konsep, sehingga diharapkan mengutamakan pada pengembangan kemampuan komunikasi dan estetika

2) Konstruksi berhubungan dengan penggunaan bahasa, susunan kalimat, kosa kata, tingkat kesukaran, dan kejelasan dalam LKA. Menggunakan bahasa yang sesuai dengan usia anak, menggunakan kalimat yang jelas dan mudah dipahami, memiliki tata urutan pelajaran yang sesuai dengan kemapuan anak, hindari pertanyaan yang terlalu terbuka, tidak mengacu pada buku sumber diluar untuk memberi keleluasaan anak dalam menulis dan menggambarkan pada LKA, menggunakan kalimat sederhana dan pendek, lebih banyak menggunakan ilustrasi daripada kata-kata, memiliki tujuan pembelajaran yang tepat, dan tersedianya identitas untuk memudahkan administrasinya. 
3) Teknis, berhubungan dengan penyajian lembar kerja siswa yang meliputi tulisan, gambar dan penampilan. Tulisan membahas mengenai jenis hurup yang digunakan, ketebalan huruf dan penggunaan kata. Gambar yang digunakan harus dapat menyampaikan pesan/isi dari gambar tersebut secara efektif kepada pengguna LKS. Penampilan LKS untuk anak perlu dibuat semenarik mungkin. Kombinasi antara tulisan dengan gambar harus seimbang. Sehingga dapat menarik anak.

Dari penjelasan tersebut dapat disimpulkan bahwa LKA merupakan lembar kerja berisi langkah-langkah kerja bergambar yang membantu proses pembelajaran untuk memudahkan anak dalam memahami isi materi.

\section{METODE PENELITIAN}

Teknik pengumpulan data yang digunakan oleh peneliti ialah observasi, wawancara, dokumentasi, dan expert judment. Metode penelitian yang digunakan peneliti untuk mengembangkan Lembar Kerja Anak (LKA) model STEM ini mengacu pada model pengembangan EDR. Peneliti menggunakan model EDR menurut Revees (dalam Lidinillah, 2012, hlm. 14) adalah sebagai berikut:

\section{Gambar 3.1 Model Generik EDR (McKenny \& Reeves, 2012)}

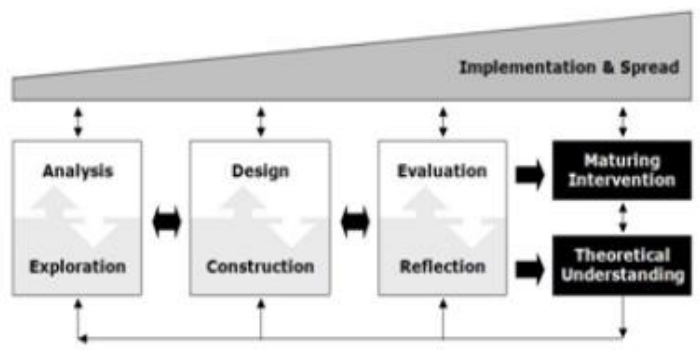

Berdasarkan gambar tersebut, tahapan penelitian EDR yaitu :

1) Tahap analisis dan Eksplorasi (Analysis dan Eksploration)

2) Tahap Desain dan Kontruksi (Design and Contuction)

3) Tahap Evaluasi dan Refleksi (Evaluation and Reflection)

Dalam penelitian ini, dilakukan sampai pada tahap desain dan kontruksi, karena membahas mengenai racangan lembar kerja anak model STEM pada konsep terapung melayang tenggelam untuk memfasilitasi keterampilan saintifik anak usia dini yang akan dibuat oleh peneliti.

\section{HASIL DAN PEMBAHASAN}

a. Tahap Analisis dan Eksplorasi (Analysis dan Eksploration)

Berdasarkan studi literatur mengenai lembar kerja anak kebeberapa TK di Kota Tasikmalaya didapatkan hasil bahwa di PAUD masih belum neggunakan pembelajaran model STEM dikarenakan guru belum memahami betul mengenai STEM dan baru mendengar istilah tersebut. Namun untuk pembelajaran sains sudah dilakukan di PAUD. Banyak sekali konsep sains yang dapat diajarkan pada anak usai dini, tetapi tidak dibantu oleh lembar kerja anak. Lembar Kerja Anak merupakan lembaran-lembaran yang berisi petunjuk atau langkah kerja pembelajaran dalam membantu siswa untuk memahami materi belajar. Hasil studi literatur oleh peneliti terhadap penggunaan Lembar Kerja Anak yang dilakukan oleh Purnamasari (2017) menyatakan bahwa

"LKA yang digunakan di PAUD belum maksimal dalam meningkatkan berpikir kreatifnya. LKA kebanyakan berisikan materi secara singkat dan soal yang 
harus dikerjakan oleh siswa. Meskipun sudah dapat mendukung anak dalam belajar namun masih dirasa kurang untuk membuat siswa aktif dalam belajar" (hlm. 3)

LKA yang digunakan di PAUD masih belum dapat memenuhi kebutuhan anak untuk lebih aktif dan membantu dalam memahami konsep dengan cara berpikir kreatifnya sendiri. Terutama pada pembelajaran sains yang dianggkap kurang efektif jika menggunakan LKA. Urgensinya, LKA digunakan sesuai kebutuhan mengajar guru dan kondisi anak. Sebaiknya, LKA dijadikan sebagai alat untuk membantu siswa dalam mencapai perkembangannya melalui kegiatan pembelajaran, sehingga setiap kegiatan belajar ada LKA nya. Hasil wawancara pada Guru kelompok B TK PGRI Handayani menjelaskan bahwa pada sekolah tersebut belum meggunakan pembelajaran STEM, karena belum mengetahui istilah dari STEM sendiri. Pembelajaran sains sudah dilakukan dengan berbagai percobaan langsung, tetapi dalam pembelajaran sains tidak dilakukan dengan menggunakan LKA seperti langkah kerja, karena dirasankurang efektif jika menggunakan langkah kerja pada usia dini, lebih baik dilakukan dengan percobaan langsung. Sedangkan, hasil wawancara pada Guru kelompok B TK Artanita untuk istilah STEM juga masih sama belum mengetahui istilah STEM namun pembelajaran sains sudah sering dilakukan, hampir setiap hari ada pembelajaran sains yang dilakukan. Untuk penggunaan LKA pun dalam pembelajaran sains digunakan berupa langkah kerja, namun masih dalam jenis lembar kerja klasikal yaitu langkah kerja yang dituangkan dalam media karton dan ditempel didepan kelas. Sehingga belum ada LKA yang memfasilitasi keterampilan saintifik anak, yaitu mengamati, mengklasifikasi dan mengomunikasikan dalam pembelajaran sains khususnya konsep terapung melayang tenggelam.
Berdasarkan pernyataan diatas, maka perlu adanya pengembangan lembar kerja anak model STEM pada konsep terapung melayang tenggelam untuk memfasilitasi keterampilan saintifik anak usai dini.

\section{b. Desain dan Kontruksi (Design and Contruction)}

Pengembangan lembar kerja anak ini dibuat dengan merujuk pada Rencana Pelaksanaan Pembelajaran Harian (RPPH) di PAUD yang dibuat oleh anggota tim penelitian. Peneliti akan mengembangkan lembar kerja anak yang sesuai dengan kurikulum 2013. Pengembangan lembar kerja anak ini ditujukan untuk anak kelompok B usia 5-6 tahun dengan Tema Alat Transportasi, Sub Tema Alat Transportasi Air dan Sub-sub Tema Konsep Terapung Melayang Tenggelam. Jenis lembar kerja anak yang dikembangkan ialah lembar kerja indidual atau personal yang diberikan kepada masing-masing anak. Bentuk dari lembar kerja anak sendiri adalah lembar kerja yang dapat membantu siswa untuk menemukan suatu konsep yaitu terapung melayang tenggelam. keterampilan saintifik yang difasilitasi oleh lembar kerja anak ini secara sfesifik yaitu mengamati, mengklasifikasi dan mengkomunikasikan. Berikut merupakan rancangan lembar kerja anak yang dikembangkan oleh peneliti:

Tabel 4.1

Rancangan Lembar Kerja Anak Model

STEM pada Konsep Terapung Melayang

Tenggelam untuk Memfasilitasi

Keterampilan Saintifik Anak Usia Dini

\begin{tabular}{|c|l|}
\hline Desain & \multicolumn{2}{|c|}{ Keterangan } \\
\hline lembor kero Anok & Cover didesain dengan \\
memperhatikan tema \\
dan materi yang akan \\
disampaikan yaitu tema \\
transfortasi air dan \\
materi & mengenai \\
\hline
\end{tabular}




\begin{tabular}{|c|c|}
\hline & $\begin{array}{l}\text { terapung melayang } \\
\text { tenggelam. gambar } \\
\text { disesuaikan dengan } \\
\text { percobaan yang akan } \\
\text { dilakukan. Dalam cover } \\
\text { terdapat petunjuk kerja } \\
\text { serta usia anak. Dan } \\
\text { juga terdapat kolom } \\
\text { nama, kelas, sekolah } \\
\text { serta kolom nilai. }\end{array}$ \\
\hline 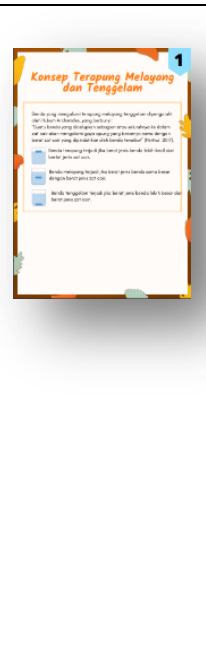 & $\begin{array}{lr}\text { Pada halaman ini } \\
\text { menjelaskan tentang } \\
\text { materi } r \text { yang } \\
\text { disampaikan yaitu } \\
\text { konsep terapung } \\
\text { melayang tenggelam. } \\
\text { Anak-anak diberitahu } \\
\text { terlebih dahulu materi } \\
\text { mengenai konsep } \\
\text { yang akan dipelajari } \\
\text { sesuai dengan prinsip } \\
\text { STEM. }\end{array}$ \\
\hline 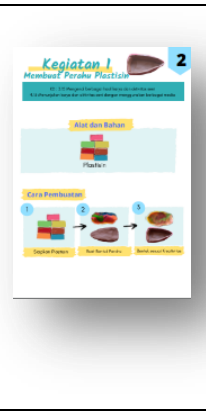 & $\begin{array}{l}\text { Pada kegiatan } 1 \text { terdapat } \\
\text { KD dan gambar } \\
\text { disamping judul untuk } \\
\text { mengilustrasikan } \\
\text { kegiatan. Terdapat alat } \\
\text { bahan dan juga langkah- } \\
\text { langkah pembuatan } \\
\text { perahu. }\end{array}$ \\
\hline 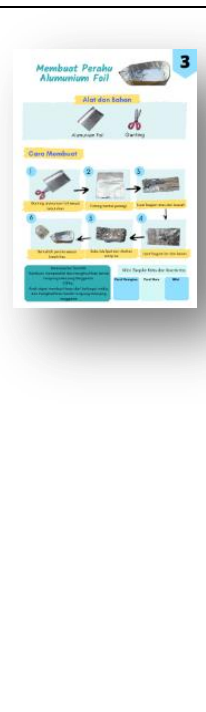 & $\begin{array}{l}\text { Seperti pada halaman } \\
\text { sebelumnya, pada } \\
\text { halaman ini menjelaskan } \\
\text { mengenai pembuatan } \\
\text { perahu dari alumunium } \\
\text { foil. Namun, pada } \\
\text { bagian bawah terdapat } \\
\text { kolom keterangan } \\
\text { keterampilan saintifik } \\
\text { dan STPPA yang harus } \\
\text { dicapai oleh anak. Juga } \\
\text { terdapat kolom nilai, } \\
\text { tandatangan orang tuda } \\
\text { dan guru. Pada halaman }\end{array}$ \\
\hline
\end{tabular}

\begin{tabular}{|c|c|}
\hline & $\begin{array}{l}\text { ini ada bagian tersebut } \\
\text { karena menunjukkan } \\
\text { bahwa kegiatan pertama } \\
\text { sudah selesai dan ada } \\
\text { proses penilaian pada } \\
\text { akhir kegiatan pertama. }\end{array}$ \\
\hline 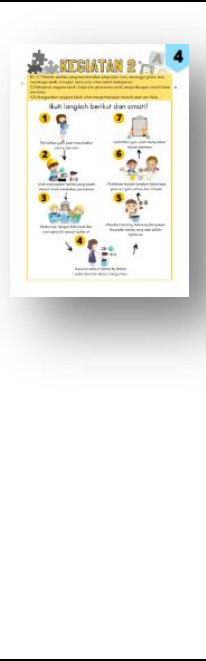 & 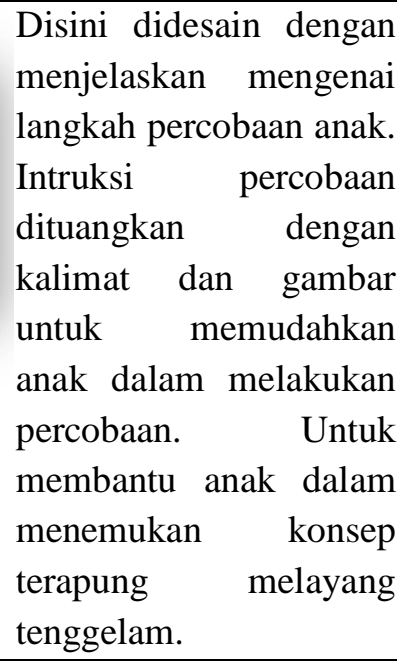 \\
\hline 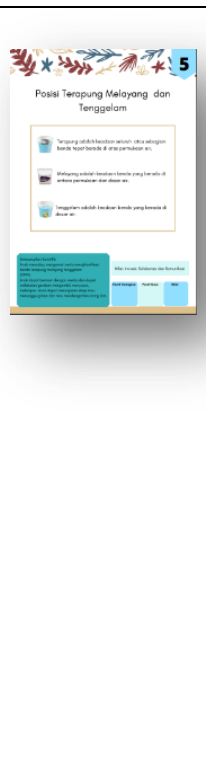 & $\begin{array}{l}\text { Informasi ini } \\
\text { disampaikan untuk } \\
\text { menguatkan penemuan } \\
\text { anak mengenai konsep } \\
\text { terapung melayang yang } \\
\text { sudah dicoba tadi } \\
\text { dengan berbagai bentuk } \\
\text { perahu, rakit dan bahan } \\
\text { lainnya. Pada lembaran } \\
\text { ini ada kolom penilaian } \\
\text { dan penjelasan } \\
\text { mengenai keterampilan } \\
\text { saintifik dan STPPA. Ini } \\
\text { menunjukan batas dari } \\
\text { kegiatan kedua. }\end{array}$ \\
\hline 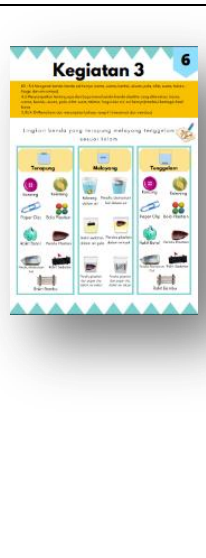 & $\begin{array}{l}\text { Kegiatan ketiga } \\
\text { menunjukan bahwa anak } \\
\text { mampu membedakan } \\
\text { mana benda terapung } \\
\text { melayang tenggelam } \\
\text { berdasarkan bentuk, } \\
\text { wujud, dan bahan yang } \\
\text { digunakan. Gambar soal } \\
\text { dibuat dengan kolom } \\
\text { agar pilihan anak dapat } \\
\text { dibedakan sesuai benda }\end{array}$ \\
\hline
\end{tabular}




\begin{tabular}{|c|c|}
\hline & $\begin{array}{l}\text { yang terapung melayang } \\
\text { tenggelam. } \\
\text { pengisian dilakukan } \\
\text { dengan melingkari } \\
\text { gambar dan kata yang } \\
\text { ada pada LKA sesuai } \\
\text { dengan hasil percobaan } \\
\text { anak, supaya anak dapat } \\
\text { mengekspresikan } \\
\text { pengetahuannya tentang } \\
\text { apa yang mereka } \\
\text { temukan sendiri }\end{array}$ \\
\hline 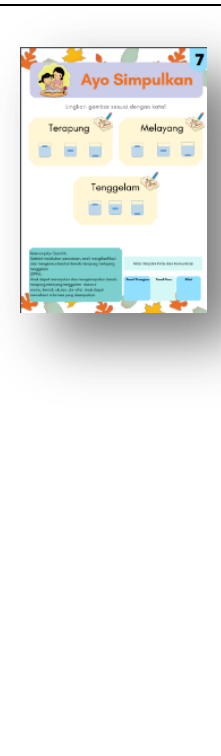 & $\begin{array}{l}\text { Pada LKA ini ada } \\
\text { bagian kesimpulan. } \\
\text { Judul kesimpulan } \\
\text { dibedakan dengan judul } \\
\text { kegiatan ketiga untuk } \\
\text { menegaskan bahwa ini } \\
\text { merupakan kegiatan } \\
\text { akhir dari inti. Namun, } \\
\text { masih dalam kegiatan } \\
\text { inti ketiga masih dan } \\
\text { dalam konten yang } \\
\text { sama. Anak memilih } \\
\text { gambar sesuai dengan } \\
\text { kata yang tersedia } \\
\text { dengan cara melingkari. }\end{array}$ \\
\hline
\end{tabular}

Struktur dari lembar kerja anak tersebut ialah, judul, petunjuk belajar, kompetensi yang ingin dicapai, langkah-langkah pembelajaran dan juga tugas-tugas yang harus dikerjakan oleh anak. Pengembangan tersebut disusun berdasarkan indikasi syarat lembar kerja yang layak digunakan menurut Hendro Darmodjo dan Jenny, yitu syarat didaktik, konstruksi dan teknis.

\section{KESIMPULAN}

Berdasarkan pembahasan diats dapat disimpulkan bahwa peneliti mengembangkan lembar kerja anak model STEM pada konsep terapung melayang tenggelam untuk memfasilitasi keterampilan saintifik anak usai dini. Pengembangan tersebut didasarkan pada hasil studi literatur dan studi lapangan yang dilakukan oleh peneliti. Masalah yang ditemukan pada saat studi pendahuluan ialah penggunaan lembar kerja anak model STEM pada pembelajaran sains khususnya konsep terapung melayang tenggelam masih belum optimal, karena hanya berisiskan soal evaluasi untuk anak dan kurang memperhatikan tingkat perkembangan anak. Solusi yang diberikan oleh pemenilti berdasarkan masalah yang ditemukan ialah pengembangan lembar kerja anak model STEM berupa langakh kerja yang dapat membantu anak dalam menemukan konsep terapung melayang tenggelam serta memfasilitasi keterampilan saintifik anak usia dini.

\section{SARAN}

Saran dari penulis untuk permasalahan ini ialah, diharapkan guru lebih memperhatikan tingkat pencapaian anak dalam pembuatan lembar kerja anak. Tidak hanya soal evaluasi saja namun dengan langkah kerja agar anak dapat menemukan sendiri pengetahuannya melalui pembelajaran. Diharapkan juga lembar kerja anak dapat memfasilitasi keterampilan saintifik anak usia dini yang sesuai dengan tuntutan kurikulum 2013.

\section{DAFTAR PUSTAKA}

Firman, H. (2015). Pendidikan Sains Berbasis Stem: Konsep, Pengembangan, Dan Peranan Riset Pascasarjana Universitas Pendidikan Indonesia.

Grossman, S. (1996). The Worksheet Dilemma: Benefits of Play-based Curricula. Earlychildhood News, 8 (4), 10-15. 
Gultom, E. L. (2017). Penerapan Pendekatan Saintifik Pada Pembelajaran Untuk Penanaman Kompetensi Inti. Prosiding Seminar Nasional Tahunan Fakultas Ilmu Sosial Universitas Negeri Medan, 1 (1). 365-370. ISSN: 2598-2796

Hosnan, M. (2014).Pendekatan Saintifik dan Kontekstual dalam Pembelajaran Abad 21. Bogor: Ghalia Indonesia.

Klarissa, N.W.E., dkk. (2018). Pengaruh Pendekatan Saintifik terhadap Kemampuan Sains Permulaan Anak Kelompok B3 TK Sila Chandra 1 Batubulan: Jurnal Pendidikan Anak Usia Dini, 6 (3), hlm. 282-292

Lidinillah, D., A., M. (2012). Educational Design Research: a Theoretical Framework for Action.

McKenney \& Reeves. (2012). Educational Design Reasearch. London: Routledge

Permendikbud RI Nomor 146 Tahun 2014 tentang Kurikulum 2013 Pendidikan Anak Usia Dini

Pertiwi, R. S. (2017). Pengembangan Lembar Kerja Siswa Dengan Pendekatan Stem (Science, Technology, Engineering, Mathematics) Untuk Melatih Keterampilan Berpikir Kreatif Siswa Pada Materi Fluida Statis. (Tesis). Sekolah Pascasarjana, Universitas Lampung, Bandar Lampung.

Prastowo, A. (2012). Panduan Kreatif Membuat Bahan Ajar Inovatif. Jogjakarta: DIVA Press.
Purnamasari, R. (2017). Analisis Lembar Kerja Untuk Anak Usia Dini Di Taman Kanak - Kanak Wilayah Banjarejo, Boja, Kendal. (Skripsi). Sekolah Strata Satu, Universitas Negeri Semarang, Semarang.

Rini, R. Y., \& Margono, S. (2019). Implementasi Pendekatan Saintifik sebagai Pembentuk Keterampilan Proses Sains Anak Usia Dini. Pros. Seminar Nasional Pendidikan FKIP. p-ISSN 2620-9047. 2 (1), hlm. 96-105

Roberts, A., \& Cantu, D. (2012). Applying STEM Instructional Strategies to Design and Technology Curriculum: Departement Of STEM Education and Proffesional Studies Old Doinion University, Norfolk, VA, U.S.A.

Rostiana, N., I. (2019). Pengembangan Lembar Kerja Siswa pada Pembelajaran Berbasis STEM untuk Mencapai Kemampuan 4C di SD. (Skripsi). Sekolah Strata Satu, Universitas Pendidikan Indonesia Kampus Tasikmalaya.

Rusman. (2017). Belajar \& Pembelajaran Berorientasi Standar Proses Pendidikan. Jakarta: Kencana

Sujiono, Y. N. (2011). Konsep Dasar PAUD. Jakarta: PT INDEKS

Sukmana, R.W. (2017). Pendekatan Science, Technology, Engineering and Mathematics (STEM) Sebagai Alternatif dalam Mengembangkan Minat Belajar Peserta Didik Sekolah Dasar. Universitas Langlangbuana. 
Suyadi \& Ulfah, M. (2013). Konsep Dasar PAUD. Bandung: PT Remaja Rosdakarya

Umiyati dkk. (2018). Pengembangan Lembar Kerja Peserta Didik Materi Bentuk-bentuk Geometri Berbasis Saintifik Anak Kelompok B Di Taman Kanak-Kanak. 1 (1), 122-131 